\title{
IMPORTANCE OF EURO-ATLANTIC INTEGRATION: DEMOCRACY, SECURITY AND ECONOMIC DEVELOPMENT
}

\author{
Gia Zoidze ${ }^{1}$
}

\begin{abstract}
The article overviews that international organizations play an important role in managing and reforming the security sector. These organizations provide expertise, advice, and knowledge enhancements on security issues; Trainings on financial capacity building issues; Programs and projects on important topics such as technical skills development, security sector management, oversight and conscientiousness. In recent times, a number of studies have been devoted to the prospects of NATO-Georgia relations and its deepening. There are always conversations about the reasons why Georgia needs to join Euro-Atlantic Alliance. However, in this regard, Georgia first needs to give NATO member states some important reasons why they would benefit from Georgia's membership in EuroAtlantic Alliance. The main reason for this may be the fact that without a secure and stable Black Sea region, the security and stability of Europe is inconceivable. According to the author of the article, the process of rapprochement and eventual accession to NATO, in addition to guaranteeing security, promotes and improves the institutional framework of the economy, the rule of law, effective governance systems, corporate security, and the reduction of uncertainty and externalities, which, in turn, provides stability, reduces political risk, facilitates foreign direct investment and trade. Consequently, liberalizing the country's economy and shifting to market principles reduces social pressures, ensures increased prosperity and the accumulation of wealth. As a result, society becomes more protected and less vulnerable when it comes to various types of external and internal shocks.
\end{abstract}

Key words: Euro-Atlantic Alliance, integration, security, economic development.

JEL Classification: F15, F63, P16

\section{Introduction}

International organizations play a crucial role in setting norms and standards, ensuring accountability, and upholding the rule of law. These organizations are the communication channel between governments and societies, between nations, and other international actors involved in security sector management and reform.

International organizations became more active in the field of security sector reform in the 1990s, when it became apparent that development efforts, especially in a conflict and post-conflict context, could not have been successful in a low-security environment. Security management has since become an integral part of institutional construction, governance, development and reconstruction projects. At the same time, democratic oversight of the security sector has become a necessary condition for partnership and membership with institutions such as NATO and the Council of Europe (Geneva Centre for Security Sector Governance, Security Sector Integrity, International Organisations).

Corresponding author:

${ }^{1}$ Batumi State University \& Batumi State Maritime Academy, Georgia.

E-mail: giazoidze@yahoo.com

ORCID: https://orcid.org/0000-0002-0155-5775

ResearcerID: https://publons.com/researcher/4610363/gia-zoidze/

\section{Euro-Atlantic integration in the political and economic aspects}

The country's economic development largely depends on the country's ability to ensure longterm security and stability by creating strategically important narratives and frameworks that, on the one hand, create the conditions for favorable cooperation of economic agents and, on the other, facilitate the country's integration into regional and international supply chains (Kutelia, 2016).

It is true that the economic development and prosperity of the country is not the main goal of NATO, but its function - to guarantee security, ensures the political and economic stability of the country. It can be said that economic development is a central aspect of a country's foreign policy, because without sufficient economic means the state will not be able to exert direct or indirect pressure on current events at the global level. Consequently, economic development is directly linked to a country's ability to facilitate the existence of an international military 


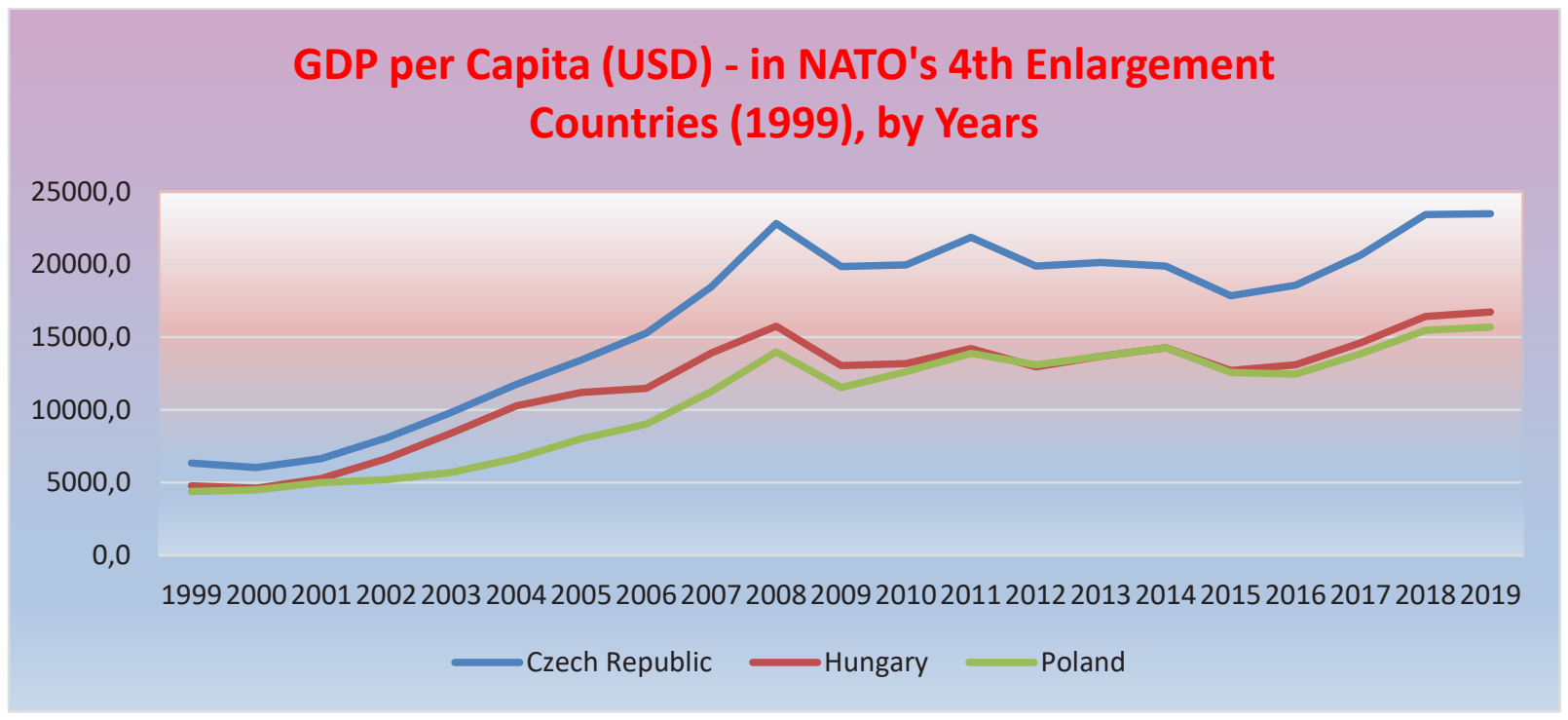

Figure 1. GDP per capita - Dynamics of 1999-2019 data from the 4th NATO enlargement countries (1999) (Czech Republic, Hungary, Poland)

Source: The figure is compiled by the author based on data from World Bank

force to overcome challenges to global security (Kutelia, 2016).

Significant positive economic effects are evident in countries where NATO membership has been decided and comprehensive reforms are underway to achieve political, economic and military compatibility with the Allies. To support this view, we can look at the data dynamics of NATO 4th, 5th, 6th, 7th, 8th enlargement countries and NATO aspirant countries (Georgia, Ukraine, Bosnia-Herzegovina) 1999-2019 (Figure 1, Figure 2 and Figure 3).

The main positive effects of NATO membership on the economic development of the above associated countries can be assessed in terms of foreign direct

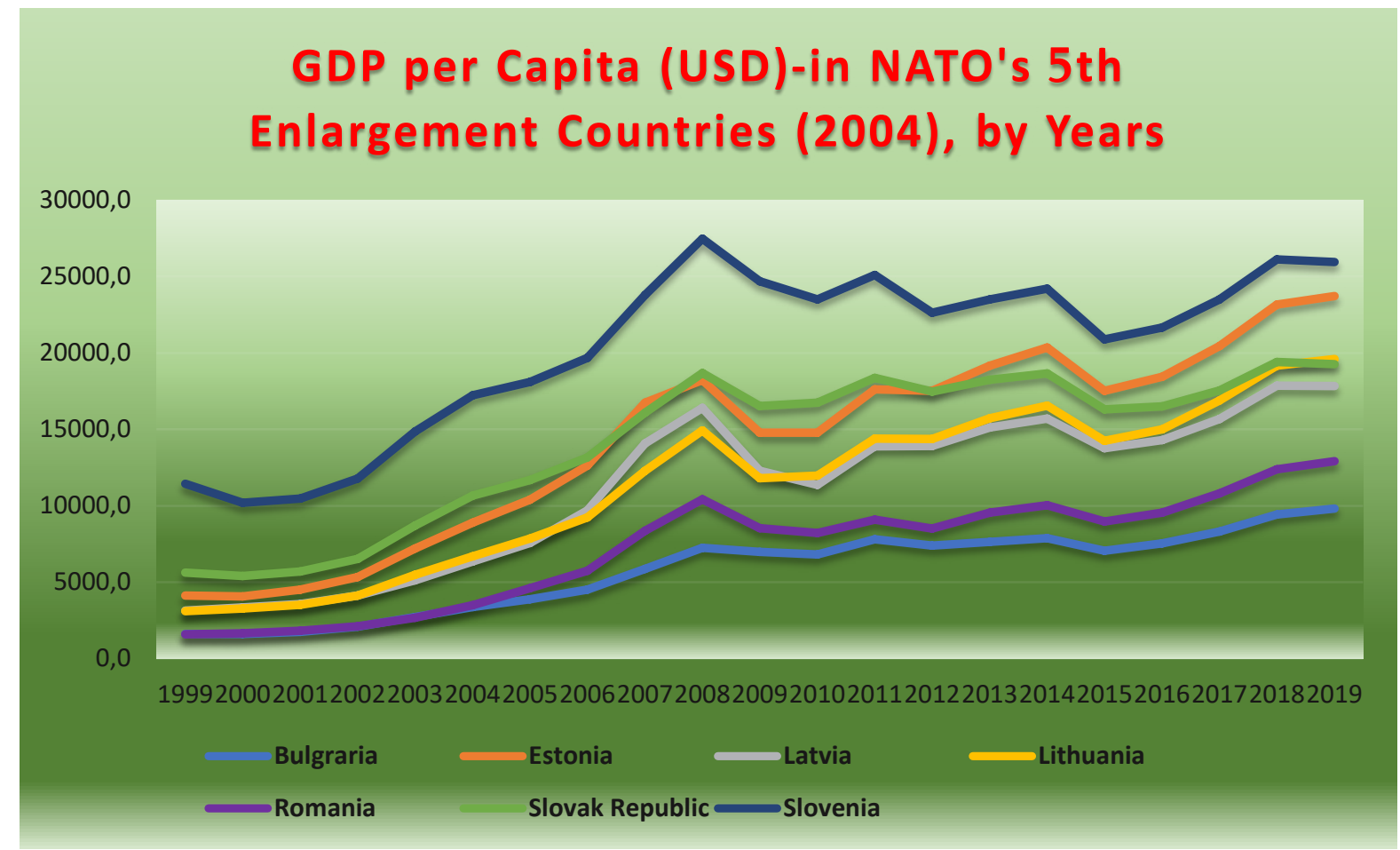

Figure 2. GDP per capita - Data dynamics of the countries of NATO 5th enlargement (2004)

(Bulgaria, Estonia, Latvia, Lithuania, Romania, Slovak Republic, Slovenia) 1999-2019

Source: The figure is compiled by the author based on data from World Bank 
investment and a safe and secure business climate. However, there are other areas from which NATO membership can benefit, as they are also related to the country's economic development and stability, as well as the creation of institutional frameworks for successful state-building (Kutelia, 2016).

A safe, secure and stable environment is a fundamental prerequisite for attracting investment and rapid economic development. This factor is crucial for the simple reason that no one will create material wealth where there are no guarantees of the protection and security of that wealth.

Attracting investment is unthinkable in a country where the state fails to ensure the security and protection of investments that make up its territories, population, and wealth; In a country where unidentified military groups can cross into state territory and seize specific property.

The fact is that this problem affects not only the investment attractiveness of a particular region of the country. Such facts affect the investment climate of the country as a whole, because the message to existing and potential investors is clear: the state cannot defend its territories and cannot ensure the defense and security of the country. Creating an investment environment in such conditions is unthinkable.

\section{The main strategic orientations of Georgia and NATO}

Defense and security, according to the Constitution, is one of the primary obligations of the state. The state must ensure the protection and security of its territories, citizens and legal entities. Everyone in the country should feel protected. If this is not the case, then the state does not or cannot perform its function. It is important to note that the key is not what reality is, but how people and investors perceive that reality.

The goal of Georgia's Euro-Atlantic integration is to protect Georgia's security and sovereignty and to develop the country, which should ensure the security and well-being of its citizens. Georgia's integration with NATO and the EU means a tradition-based and new knowledge-based economy, the rule of law, high military standards, better education and health care (Tsereteli, 2016).

More specifically, increasing the country's security (NATO integration) will provide:

- Additional political, economic, social and security guarantees for Georgia as well as for the whole region (South Caucasus);

- Peaceful and stable development of the country;

- High military standards;

- Opportunity to increase Foreign Direct Investment;

- Increasing the share of expenditures on education and innovation;
- Reducing unemployment and improving social status;

- Increase investment in healthcare in response to increasing demand for it;

- A sharp drop in loan interest rates;

- Increased flows of tourists entering the country in the footsteps of security;

- Solving the chronic problem of budget deficit at the expense of increasing foreign direct investment;

- Sustainability of the economy against internal or external shocks;

- Getting closer to European institutions;

- Striving to reduce corruption;

- Increase in average life expectancy;

- Balancing territorial problems, which will help increase the country's international prestige;

- Increasing the standard of living, which will contribute to receiving higher professional education and more involvement of qualified staff in various fields: agriculture, tourism, science, education, industry...;

- Development of art fields (theater, cinema, music, painting) as a result of increasing living standards;

- Return of Georgia to a large European and EuroAtlantic family (NATO is a community of democracies, and with Georgia's integration into NATO, we are, in fact, returning to a large European and Euro-Atlantic family from which we have unfortunately been "excluded" for a long time).

Here we should mention the specific factors why Georgia's Euro-Atlantic integration is a top priority for NATO itself:

1. The key factor: without a secure and stable Black Sea region, the security and stability of Europe is unimaginable.

2. Given its good location and full realization of its transit potential, the region can significantly diversify its energy supply to Europe and become a guarantor of future European energy security.

3. At the same time, it should be noted with great pride that today we act as a de facto ally, we are not only consumers but also security providers. Georgian military units are actively participating in peacekeeping operations in Kosovo, Iraq and Afghanistan.

4. Georgia's integration into NATO is beneficial for Europe because it will expand the democratic space to the east. To further improve democracy in the Caucasus, Europe will benefit from a common safe spaces and reliable partners in order to achieve international security and stability.

5. Georgia's accession to the Euro-Atlantic security system will significantly reduce modern security threats to Europe, such as terrorism, arms and drug trafficking, trafficking, illegal migration and organized crime.

6. Following the accession of Bulgaria and Romania, the EU directly borders the Black Sea, making this area 
an integral part of European trade, security and the legal sphere.

7. The overall task is to establish and strengthen a Black Sea security system. This system will be linked to the Mediterranean security system and will be the final stage of the security of the United Europe. Consequently, the Black Sea basin will be of even greater strategic importance to the EU and NATO, both politically and militarily, and so on.

The Black Sea region has always been a place of intense socio-economic relations and it is increasingly transformed into a center of attraction for the growing political and economic interaction of various actors. Against the background of the growing economic interdependence of the countries of the region and not only, there are more and more new opportunities and challenges intertwined. Unfortunately, the political interest in creating dividing lines and zones of influence has a negative impact on the political and economic situation in the region, as well as on the overall picture of interpersonal relations (Ministry of Foreign Affairs of Georgia).

In addition to stabilizing the local economy, NATO membership also stimulates foreign investment. This is evidenced by Estonia, where, after joining NATO, foreign investment has increased considerably. A similar trend was observed in Albania, Bulgaria, Latvia and Lithuania. In all these countries, foreign investment has increased significantly, the level of which, despite the severe impact of the economic crisis of 2008, still remained at a high level compared to 2000.

Even in the case of Slovenia, despite its unstable development path, foreign investment increased before the onset of the economic crisis, and in 2014 the level of foreign investment was quite high compared to previous years. Such a trend can be seen as a product of political stability and military security that NATO membership brings, as NATO membership is one of the guarantees for foreign investors to minimize political and economic unpredictability and increase the potential for investors to succeed in these markets (Kutelia, 2016).

Due to these increased activities in economic and various directions, there is a sharp increase in the GDP per capita of the newly joined NATO countries (Figure 1, Figure 2, Figure 3).

\section{The impact of European integration on the level of education in the country}

In democracies with open and free market economies, there is a direct correlation between the share of investment (private or public) in education, research and development and job creation, investment growth, which over time is reflected in improved employment and living standards (Kutelia, 2016).

The Euro-Atlantic integration path underscored the importance of developing an educated and competent workforce needed to ensure strong, sustainable and

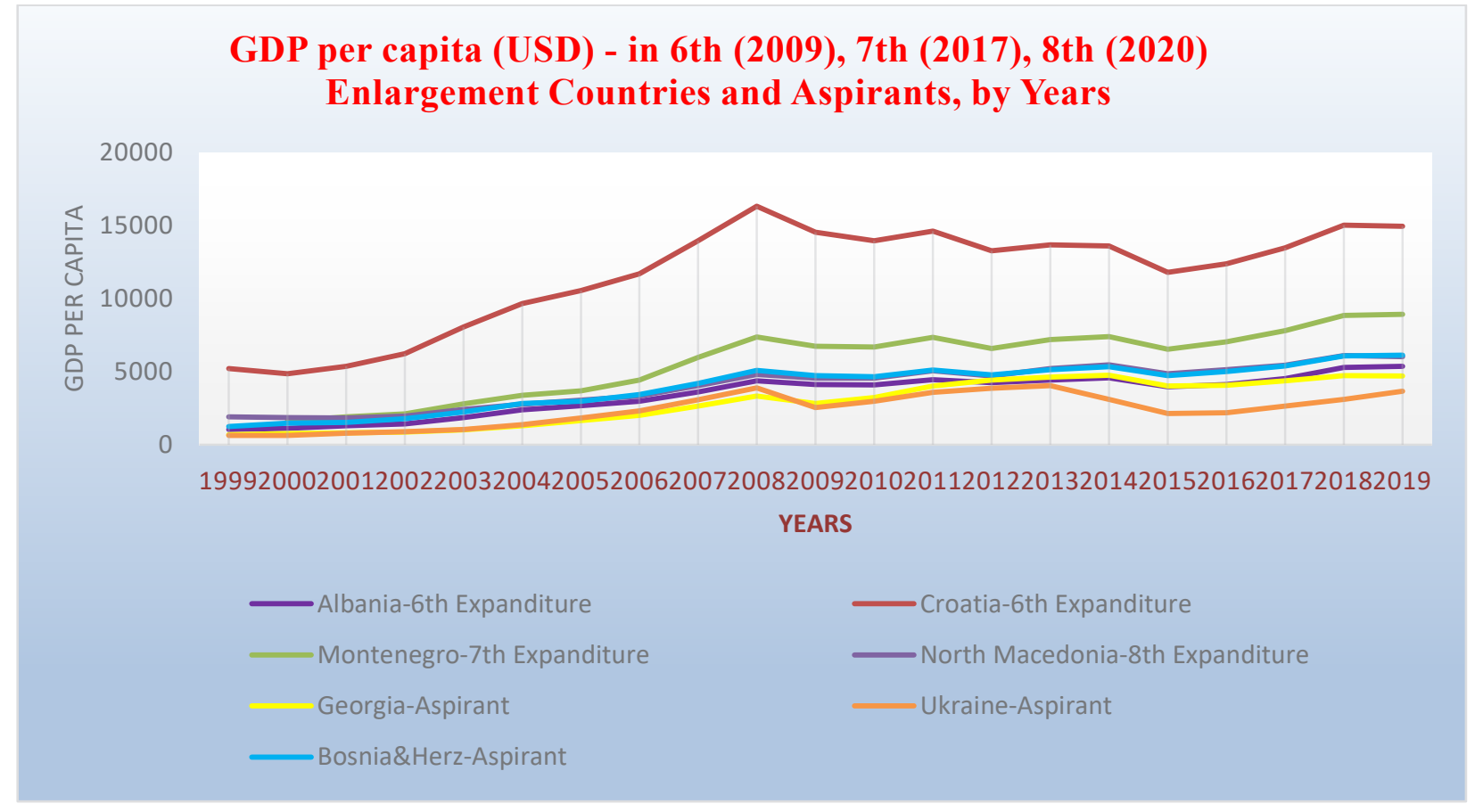

Figure 3. GDP per capita - NATO 6th (2009), 7th (2017), 8th (2020) enlargement countries and NATO aspirant countries (Georgia, Ukraine, Bosnia-Herzegovina) 1999-2019 data dynamics

Source: The figure is compiled by the author based on data from World Bank 
balanced growth in the candidate countries. Therefore, the new NATO member states, which have a guarantee of collective security, have been able to increase spending on education.

The growing investment in education over the years has created a relatively cheap and educated workforce in the new NATO member states and, consequently, increased the potential for further investment in research, development and new technologies. Therefore, it is vital for Georgia to increase spending on education, as it is directly related to reducing unemployment and social spending, as well as increasing the overall income of citizens, which contributes to increasing capital in the economy (Kutelia, 2016).

Due to the growth of economic globalization, which is accompanied by the integration of new NATO member states (large or small) into the Alliance, there is a growing possibility that NATO member states, to varying degrees, remain vulnerable to global or regional trends and become dependent on them; However, the fact that the above countries have already been able to increase investment in education, research, development and technology - and consequently diversify their economies - makes them more resilient to external and domestic shocks. The formation of a healthy and competitive economy can be a source of long-term (continuous) improvement of the overall quality of life of citizens and equal distribution of income.

In addition, low unemployment is one of the main indicators of a market economy, as low unemployment is a result of the high purchasing power of citizens in the country, which allows them to purchase high quality products, food and health services (Kutelia, 2016).

As an increase in the quality of education and a decrease in the unemployment rate towards higher wages, the above trends provide a basis for improving life expectancy as citizens have access to high quality medical services. Thus, there is a strong correlation between citizens' total income and access to quality health services.

It is true that the effect of improving life expectancy is not seen in the short term, but the long-term result of increased investment in the health care system, capacity building and optimal resource management is a healthier population with longer life expectancy and a more active role in the country's economy. This alleviates the social burden of the country. The above healthy trends will significantly improve the equal distribution of income in the country and the ability of the government to spend funds more purposefully and efficiently (Kutelia, 2016).

Collective security guarantees provide a solid foundation for closer regional economic and political integration, economic diversification and resilience. Integration is a source of promoting economic prosperity, peace and security in the region through the development of a liberalized economy and political strategies between participating countries.

\section{Conclusions}

New membership for NATO has brought greater opportunities for long-term economic growth. The primary effect of NATO and EU membership was to strengthen the economy, which would ensure the country's security and economic stability. The stability that NATO membership has brought was quite important in stimulating foreign direct investment. Given that NATO membership provided the country with political strength and protection from external shocks, NATO integration has intensified the efforts of the newly formed countries to achieve long-term prosperity. The "NATO effect" can be manifested through a simple but effective cycle that brings significant benefits to ordinary citizens.

NATO involvement in the process of strengthening Black Sea security is extremely important and Georgia, as a country interested in peace and stability in the region, should continue to deepen close cooperation with the Alliance in all areas.

It should be noted that the stability of Georgia and Ukraine and their integration into the Euro-Atlantic space are of special importance for the security of the Black Sea region. Since 2014, both countries have been actively involved in discussions and initiatives on Black Sea security within NATO, enabling them to move even closer to Alliance standards and increasing the prospects of joining the Collective Defense Organization.

The main principle should be lobbied and put into practice, so that the security of Georgia should be in the strategic interest of all neighbors and global actors. This, of course, cannot be conditioned by militarypolitical factors alone. If the United States in Georgia is directly viewed in terms of the sustainability, growth and guarantee of military defense (military-technical cooperation and increased joint exercises), which is logical, the EU should focus on achieving the goals set by the Neighborhood Policy and Association Agreement, both political and especially, in economic terms.

Georgia's accession to NATO will bring security, a stable political and socio-economic environment to the country, which will increase international interest in investing in Georgia. This will lead to an increase in the income of the country's population, which in turn will be reflected in a significant increase in GDP per capita. This will improve the socio-economic situation of the society. Examples of this are the recent increase in the GDP per capita of the new member states of NATO. That is why institutional reforms must be carried out in Georgia as soon as possible in areas where there is 
a sharp lag behind similar figures to NATO member states.

It should also be emphasized that Georgia's integration into NATO is very important for each member of the Euro-Atlantic Alliance. Georgia's transit role (due to its strategic geographical location) for the development of closer trade and energy relations between Europe and Asia carries a broad context. Given its good location and full realization of its transit potential, the region can significantly diversify its energy supply to Europe and become a guarantor of future European energy security.

At the same time, Georgia's integration into NATO will be beneficial for European countries because it will expand the democratic space to the east. To further improve democracy in the Caucasus, Europe will benefit from a common safe spaces and reliable partners in order to achieve international security and stability.

\section{References:}

Aladashvili, I. (2021). "Yesterday we entered the territorial waters of Georgia ...", or what did these words of the NATO Secretary General mean, Kviris Palitra.

Geneva Centre for Security Sector Governance, Security Sector Integrity, International Organisations. Available at: https://securitysectorintegrity.com/institutions-and-organisations/international-organisations/ (accessed 23 September 2021).

German, T. (2015). Heading West? Georgia's Euro-Atlantic Path. International Affairs, 91(3), 601-614.

Hartmann, P., Maddaloni, A., \& Manganelli, S. (2003). The Euro-area Financial System: Structure, Integration, and Policy Initiatives. Oxford Review of Economic Policy, 19(1), 180-213.

Hodges, B. (2019). Interview: Accession of West Germany into NATO is a Precedent for Georgia. Voice of America. Available at: https://civil.ge/archives/276491 (accessed 23 September 2021).

Kutelia, B. (2016). The NATO effect: On the economic development of the new member states and the expected results for Georgia. Economic Policy Research Center (EPRC). Tbilisi.

Laurinavičius, Č. (2000). The Euro-Atlantic Integration and the Future of Kaliningrad Oblast. NATO Euro-Atlantic Partnership Council Individual Research Fellowships.

Magomedov, A. (2020). The main directions of economic cooperation between ukraine and NATO in the 21 st century. Three Seas Economic Journal, 1(3), 66-71.

Marelli, E., \& Signorelli, M. (2016). Europe and the Euro: Integration, crisis and policies. Springer.

National Security Concept of Georgia (2018). Government of Georgia. Available at: https://mod.gov.ge/ uploads/2018/pdf/NSC-ENG.pdf (accessed 23 September 2021).

Nosyriev, O., \& Bukina, T. (2021). SOCIO-CULTURAL TRANSFORMATION OF UKRAINE IN THE CONTEXT OF EUROPEAN VALUES. Three Seas Economic Journal, 2(1), 110-115.

Phinnemore, D. (2001). Romania and Euro-Atlantic integration since 1989: a decade of frustration? In Post-Communist Romania, pp. 245-269. Palgrave Macmillan, London.

Popova, I., \& Demchenko, N. (2020). Territorial Societies Features: European Experience. Three Seas Economic Journal, 1(1), 20-27.

Rumer, E. B., \& Simon, J. (2006). Toward a Euro-Atlantic strategy for the Black Sea region. National Defense Univ Washington Dc Inst for National Strategic Studies.

Security of the Black Sea - a chance for Georgia or a distant prospect of peace (2017). All about the association agreement with the EU. Europe for Georgia.

Sichinava, A., Chikava, M., Veshapidze, S., Sekhniashvili, D., \& Pailodze, N. (2013). Realities of internationalization of higher education in Georgia.

Tsereteli, M. (2016). Impossibility of Georgia's Neutrality. The Heinrich Böll Stiftung: Tbilisi, South Caucasus Region. Vashakidze, R., \& Gogol, A. (2020). Security and investment environment. Forbes Georgia. Tbilisi.

Veshapidze, S., \& Zoidze, G. (2021). Institutional Evolution of Higher Education in Georgia/

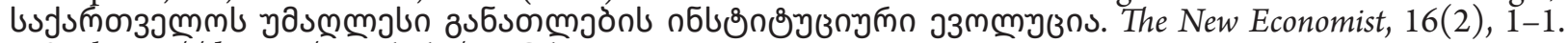
DOI: https://doi.org/10.36962/NEC6102202133

Veshapidze, S., Darbaidze, M., \& Beridze, T. (2016). Euro-Atlantic values: what tie up us.

Veshapidze, S., Chiabrishvili, K., Zubiashvili, T., \& Zoidze, G. (2021). On the relationship between education and economic security. Ecoforum Journal, 10(3).

Veshapidze, S., \& Mchedlishvili, Z. (2020). From Ilia Chavchavadze’s Economic Views: Competition, Private Property and International Trade. Ecoforum Journal, 9(2).

Veshapidze, S., \& Zubiashvili, T. (2020). About the Origins of Modern Geoeconomic Foundations of Georgia. Ecoforum Journal, 9(2).

World Bank Group (2018). Georgia: From Reformer to Performer, A Systematic Country Diagnostic. Availableat:https://openknowledge.worldbank.org/bitstream/handle/10986/29790/GEO-SCD-04-24-04272018. pdf ? sequence $=1$ \&isAllowed $=y$ (accessed 23 September 2021). 
Vol. 2 No. 3, 2021

Zoidze, G. (2020). Georgian agro-sphere development priorities and ways of carrying out some improvements. Myśl Ekonomiczna i Polityczna, 2(69), 55-71. DOI: https://doi.org/10.26399/meip.2(69).2020.10/g.zoidze Zoidze, G. (2021). Basic Paradigms of Institutional Economics. Publishing House “Universal". Tbilisi, p. 202.

Zoidze, G., \& Tkhilaishvili, G. (2021). Prospects of Intermodal Transportation and Logistics Channels Development for Georgia. In Proceedings of 25th International Scientific Conference. Transport Means.

Zubiashvili, T., \& Veshapidze, S. (2019). Labour Emigration and Employment in Georgia. Humanities and Social Sciences Review, 9(01), 127-136.

Wivel, A., \& Mouritzen, H. (2004). The geopolitics of Euro-Atlantic integration. Routledge. 